\title{
Partitioning and distribution of RAPD variation in a forest tree species, Eucalyptus globulus (Myrtaceae)
}

\author{
K. A. NESBITT†**, B. M. POTTS†, R. E. VAILLANCOURT†, A. K. WEST§ \\ \& J. B. REID††, \\ †Coopera tive Research Centre for Temperate Hardwood Forestry, Locked bag No. 2, Sandy Bay, Tasmania 7005, \\ $\ddagger$ Department of Plant Science, University of Tasmania, GPO Box 252C, Hobart, Tasmania 7001 and $\S$ Department of \\ Biochemistry, University of Tasmania, GPO Box 252C, Hobart, Tasmania 7001, Australia.
}

Eucalyptus globulus is an important species for pulpwood production in many countries. The pattern and partitioning of variation is important baseline knowledge for tree breeding. Currently the species is divided into four subspecies: globulus, bicostata, pseudoglobulus and maidenii. Random Amplified Polymorphic DNA (RAPD) markers were used to analyse variation in 173 representatives of 37 natural populations of E. globulus: 31 localities of ssp. globulus (148 individuals), two localities each of ssp. bicostata (nine individuals), ssp. maidenii (ten individuals) and ssp. pseudoglobulus (six individuals). Ten 10-mer primers amplified a total of 162 scorable bands, of which 149 (91.9 per cent) were polymorphic. AMOvA analysis of a Euclidean distance matrix based on presence/absence of polymorphic bands found most variation within localities, but significant differences between localities and regions. Principal components analysis (PCA) identified a major latitudinal cline in RAPD phenotype that differentiated southern Tasmanian localities from other ssp. globulus localities on mainland Australia. Many localities previously identified as intermediate between subspecies globulus and other subspecies in morphology were not intermediate in RAPD phenotype. In some cases regions which showed marked differentiation between localities in capsule and juvenile leaf morphology showed little RAPD differentiation between localities. RAPDs also provided new insights into the affinities of outlying localities. Although RAPD technology has not yet been applied to many forest tree species, patterns of variation were similar to those found in other outcrossing species studied using both RAPDs and other molecular markers.

Keywords: Eucalyptus globulus, genetics, RAPD, variation patterns.

\section{Introduction}

Eucalyptus globulus (Labill.) is an important species for pulpwood production and is widely planted in countries such as Spain, Portugal, Italy, Chile, India, China and Australia (Volker \& Orme, 1988; Borralho et al., 1992a). Breeding programmes aimed at improving wood quality and growth traits of $E$. globulus are established both in Australia and overseas (Volker \& Orme, 1988; Borralho et al., 1992a,b). Most breeding programmes are currently at the stage of exploiting collections made from wild populations in Australia (Jordan et al., 1993). In order to plan effectively breeding and gene conservation strategies it is essential to have an understanding of the pattern of genetic variation in these populations (Muona, 1990).

*Correspondence.
Eucalyptus globulus is divided into four subspecies: ssp. globulus, ssp. bicostata (Maiden, Blakely \& J. Simm.) Kirkpatr., ssp. maidenii (F. Muell.) Kirkpatr., and ssp. pseudoglobulus (Naudin ex Maiden) Kirkpatr., of which ssp. globulus is the most important for forestry purposes. The subspecies are differentiated mainly by reproductive characters, such as capsule and flower size and number of fruit per umbel (Chippendale, 1988). The species complex extends south from ssp. maidenii in New South Wales through ssp. pseudoglobulus and ssp. bicostata to ssp. globulus in Tasmania. While the core populations of the subspecies are geographically (Fig. 1) and morphologically distinct, extensive areas of intergradation occur between them (Kirkpatrick, 1974, 1975a,b; Jordan et al., 1993). This study uses random amplified polymorphic DNA (RAPD) markers to investigate the distribution of variability in natural populations of $E$. globulus (especially within ssp. globulus). 
Fig. 1 Localities sampled for RAPD survey of Eucalyptus globulus. Numbers correspond to those in Table 1; localities have been grouped into Southern Tasmanian (-), Northern Tasmanian and Furneaux group ( $)$, Victorian $(\square)$, and other subspecies $(\diamond)$. Symbols correspond to groupings in principal components analysis (see Fig. 3). Bold lines indicate the major core and intergrade areas of each subspecies as designated by Jordan et al. (1993), plain lines encompass areas designated as core in this study.

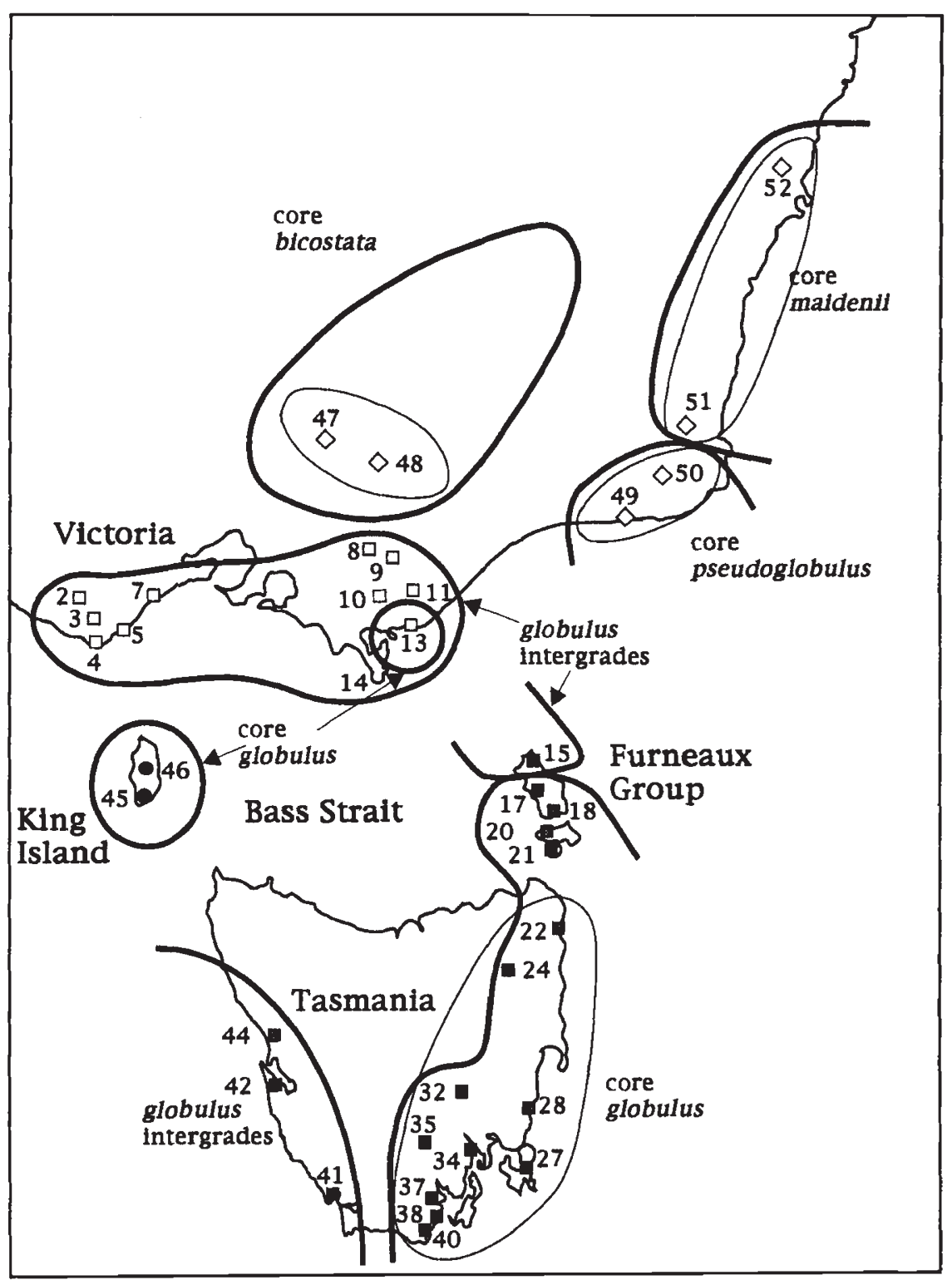

RAPDs are dominant molecular markers first developed by Welsh \& McClelland (1990) and Williams et al. (1990). They are random pieces of DNA amplified from the genome by a PCR-based technique. RAPDs have been used for genome mapping (Carlson et al., 1991; Klein-Lankhorst et al., 1991; Kazan et al., 1993; Sobral \& Honeycutt, 1993), to describe phylogenetic relationships (Puterka et al., 1993) and to identify cultivars (Hu \& Quiros, 1991; Landry et al., 1993; Mailer et al., 1994; Yu \& Nguyen, 1994). Several studies have used RAPDs to assess levels and patterns of variation (Chalmers et al., 1992; Huff et al., 1993; Landry et al., 1993; Puterka et al., 1993).

The genetic material sampled in this study is from a 600 -family collection which will form the base for breeding populations in many countries (Jordan et al., 1993) and covers the complete geographical range of ssp. globulus. The study assesses the patterns of variation within this collection. Samples of the other three subspecies are included to examine the differentiation between subspecies and to determine the genetic affinities of populations outside core areas.

\section{Materials and methods}

\section{Leaf material}

Apical tips and young leaves were used for DNA isolation in preference to more mature leaves. For $E$. globulus ssp. globulus, material was collected from 
trees grown in a trial established by North Forest Products at Massy Greene Drive $\left(41^{\circ} 05^{\prime} \mathrm{S}, 146^{\circ} 54^{\prime} \mathrm{E}\right)$ in July 1989. This trial was established from openpollinated seed collected by the CSIRO Tree Seed Centre from National populations of E. globulus ssp. globulus (Fig. 1). Samples of sspp. bicostata, maidenii and pseudoglobulus were collected from APM trials in Tasmania (Geeveston; see Volker \& Orme, 1988) and Victoria (Jeeralang). For this study, one individual per open-pollinated family was sampled from between three to five families per locality (families within about $10 \mathrm{~km}$ ). The localities are further grouped into regions (localities within 100-150 km) as shown in Table 1 . This sampling strategy was adopted to maximize the number of localities sampled and also to ensure that the full geographical range of E. globulus was sampled. Localities designated as subspecies cores and those designated as intergrades in this study are indicated in Table 1 . These core areas differ slightly from those defined by Jordan et al. (1993) based on capsule morphology (see Fig. 1) to ensure that core areas sampled were geographically distinct.

\section{DNA isolation}

DNA was extracted from $1-3 \mathrm{~g}$ of tissue using a method modified from that of Doyle \& Doyle (1990). The modifications were as follows: 10 per cent insoluble PVP and 0.4 per cent $\beta$-mercaptoethanol were used in the extraction buffer; the first precipitation was with ethanol rather than isopropanol; after the first precipitation the DNA was washed in 76 per cent ethanol $/ 0.2 \mathrm{M} \mathrm{Na}$-acetate; and before the final precipitation the salt concentration was adjusted to $2.0 \mathrm{M}$ by the addition of an equal volume of $4 \mathrm{M} \mathrm{NaCl}$ (Fang et al., 1992). DNA concentration was estimated from ethidium bromide stained gels and samples were diluted to $10 \mathrm{ng} / \mu \mathrm{L}$.

\section{PCR conditions and electrophoresis}

Amplification was carried out in a $20 \mu \mathrm{L}$ volume in microtitre plates using an MJ Research Inc. PTC-100 (MA 02172 USA) programmable thermal controller. The reaction mixture contained $200 \mu \mathrm{M}$ of each dNTP, $1 \times$ Taq polymerase buffer (Promega), $150 \mathrm{mg} / \mathrm{mL}$ BSA, $3.0 \mathrm{~mm} \mathrm{MgCl}_{2}, 10$ pmoles primer, 20 ng DNA and 1 unit Taq polymerase (Promega). The reactions were overlaid with mineral oil and amplification was performed as follows: initial $1 \mathrm{~min} 92^{\circ} \mathrm{C}$ denaturation; 35 cycles of $1 \min 92^{\circ} \mathrm{C}, 1 \min 35^{\circ} \mathrm{C}, 2 \min 72^{\circ} \mathrm{C}$; and $5 \min 72^{\circ} \mathrm{C}$ extension, using the fastest possible transitions between each temperature. Amplified fragments were separated in 1.4 per cent agarose gel using $1 \times \mathrm{TBE}$ buffer and were visualized and photographed, using polaroid film with negatives, after staining with ethidium bromide (Fig. 2).

A total of 140 Operon primers (Operon Technologies Inc., Alameda, CA), sets A, B, C, D, E, F, and $\mathrm{M}$, were evaluated for usefulness in an initial survey. Of these, 28 were found to give clear reproducible results, and 10 of these (OPC-01, OPC-19, OPD-05, OPE-03, OPE-07, OPE-14, OPE-18, OPE-20, OPF-01 and OPF-04) were eventually used in this study. Amplified bands were scored as present or absent for each DNA sample. All bands scored were between 0.5 and $2.0 \mathrm{~kb}$. One sample was repeated three times on every plate to check reproducibility. In an interspecific cross of $E$. grandis and E. urophylla, Grattapaglia \& Sederoff (1994) found that only low intensity RAPD bands were not repeatable. They also found that there was no departure from the expected Mendelian ratio in RAPD markers at the 0.01 significance level. Twenty of 500 marker loci examined showed distortion at the 0.05 level, less than expected by chance alone.

\section{Statistical analysis}

A matrix of genetic distance between individuals was obtained using a Euclidean distance measure, calculated from presence/absence data (Huff et al., 1993). To allow consideration of samples with small amounts of missing data, the distance for each pairwise comparison was based on only those bands that were scored for both samples of the pair. Components of variance attributable to differences beween regions, between localities within regions, and between individuals within localities were estimated from this matrix using AMOVA (Analysis of Molecular Variance; Excoffier et al., 1992). Separate analyses were also undertaken for each region. The number of permutations for significance testing was set at 100 for all analyses. AMOVA variance components were used as estimates of the genetic diversity within each locality and region. Eight DNA samples which had $>12$ per cent of total bands unscorable (missing) were excluded from the AMOVA analysis.

The major directions of variation between localities in RAPD phenotype were determined using principal components analysis (PCA) and the genetic similarities amongst localities and regions were summarized using Average Linkage Clustering (Sneath \& Sokal, 1973). These analyses were based on band frequencies in each locality or region. PCA of the correlation matrix and Average Linkage Clustering of squared Euclidean distances were undertaken using the PRINCOMP and CLUSTER procedures of SAS (SAS, 1988). Bands that differed significantly between subspecies cores were identified using a contingency $\chi^{2}$-test (PROC FREQ of SAS).

(c) The Genetical Society of Great Britain, Heredity, 74, 628-637. 
Table 1 Origin and classification of material collected for RAPD survey in Eucalyptus globulus

\begin{tabular}{|c|c|c|c|}
\hline Region & Locality & Code & $N$ \\
\hline \multicolumn{4}{|l|}{ Victorian intergrades } \\
\hline \multirow[t]{5}{*}{ Otway Ranges } & Otway State Forest & 2 & 5 \\
\hline & Cannon Spur & 3 & 5 \\
\hline & Parker Spur & 4 & 5 \\
\hline & Cape Patton & 5 & 5 \\
\hline & Lorne & 7 & 5 \\
\hline \multirow[t]{5}{*}{ South Gippsland } & Jeeralang North & 8 & 5 \\
\hline & Jeeralang & 9 & 3 \\
\hline & Madalya Rd. & 10 & 5 \\
\hline & Bowden Rd. & 11 & 5 \\
\hline & Hedley & 13 & 4 \\
\hline Lighthouse & Lighthouse & 14 & 4 \\
\hline \multicolumn{4}{|l|}{ West Coast intergrades } \\
\hline \multirow[t]{2}{*}{ West Coast Central } & Macquarie Harbour & 42 & 5 \\
\hline & Badgers Creek & 44 & 5 \\
\hline \multicolumn{4}{|l|}{ West Coast South } \\
\hline intergrades & & & \\
\hline Port Davey & Port Davey & 41 & 5 \\
\hline \multicolumn{4}{|l|}{ Core globulus } \\
\hline \multirow[t]{2}{*}{ East Coast Central } & Tarrana & 27 & 5 \\
\hline & Triabunna & 28 & \\
\hline \multirow[t]{2}{*}{ East Coast North } & Royal George & 24 & 5 \\
\hline & St. Helens & 22 & 5 \\
\hline \multirow[t]{3}{*}{ Derwent Valley } & Jericho & 32 & 5 \\
\hline & Hobart South & 34 & 5 \\
\hline & Moogara & 35 & \\
\hline \multirow[t]{3}{*}{ East Coast South } & South Geeveston & 37 & 5 \\
\hline & Dover & 38 & \\
\hline & Recherche Bay & 40 & 4 \\
\hline \multicolumn{4}{|l|}{ Bass Strait integrades } \\
\hline \multirow[t]{5}{*}{$\overline{\text { Furneaux Group }}$} & North Flinders Is. & 15 & \\
\hline & Central Flinders Is. & 17 & 4 \\
\hline & South Flinders Is. & 18 & 5 \\
\hline & West Cape Barren & 20 & 5 \\
\hline & Clarke Is. & 21 & \\
\hline \multirow[t]{2}{*}{ King Island } & South King Is. & 45 & 3 \\
\hline & Central King Is. & 46 & 5 \\
\hline \multicolumn{4}{|l|}{ Core bicostata } \\
\hline \multirow[t]{2}{*}{ bicostata } & Strath Bogie & 47 & 5 \\
\hline & Toombullup & 48 & \\
\hline \multicolumn{4}{|l|}{ Core pseudoglobulus } \\
\hline \multirow[t]{2}{*}{ pseudoglobulus } & Kuark-Wibens Hill & 49 & 3 \\
\hline & Orbost & 50 & \\
\hline \multicolumn{4}{|l|}{ Core maidenii } \\
\hline \multirow[t]{2}{*}{ maidenii } & Mt. Myrtle & 51 & 5 \\
\hline & Bimmil Hill & 52 & \\
\hline
\end{tabular}

$N$ is the number of individuals used in Average Linkage Clustering and the code is as used in Jordan et al. $\{1993\}$. Intergrade and core areas, as designated in this study, are indicated (underlined).

\section{Results}

A total of 162 bands was scored, 13 (8.0 per cent) of which were invariant and were excluded from analyses. Of the 149 polymorphic bands, 46 (30.9 per cent) and $95(63.8$ per cent $)$ differed significantly $(P<0.05)$ in frequency between subspecies cores (Table 2) and between localities, respectively. While band frequency varied greatly across localities and regions, no fixed differences were found.

\section{AMOVA analyses}

The results of the Amova partitioning of variance are shown in Table 3 . There were significant differences $(P<0.01)$ between subspecies cores and localities within these cores. Excluding ssp. bicostata, pseudoglobulus and maidenii from, and including intergrade localities in, the analysis reduces the percentage of variation found between regions (from 9.5 per cent to 3.5 per cent), but the differences between regions are still significant $(P<0.01)$. The greatest percentage (80.2 per cent) of the variation is found within localities, followed by localities within regions (16.4 per cent).

Total regional variability tends to increase from northern Tasmania down the west and east coasts, with the variability highest in southern Tasmania (see Table $3)$. The most variable regions were West Coast Central (15.8), Derwent Valley (15.6) and East Coast South (14.9); the Furneaux region was the least variable (13.1). In all regions most of the variation is found between individuals within localities (ranging from 73.8 per cent to 94.9 per cent; Table 3 ). With the exception of the ssp. pseudoglobulus core, all regions showed significant differences between their localities (Table 3). Differentiation between localities is greatest in the West Coast Central and East Coast North regions and on King Island. Comparatively little differentiation was detected between localities in the Furneaux and southern Victorian regions. There are no obvious geographical trends in the within-locality variability. However, the total within-locality variability for each region was highest in the Otway Ranges and lowest on King Island and in ssp. bicostata (Table 3).

\section{Principal components analysis}

The first three principal components from Principal Component Analysis (PCA) account for 30.7 per cent of the total variation between localities. The ssp. globulus group is separated from the other three subspecies by the first principal component (PC1). A combination of $\mathrm{PC} 1$ and the second principal component 


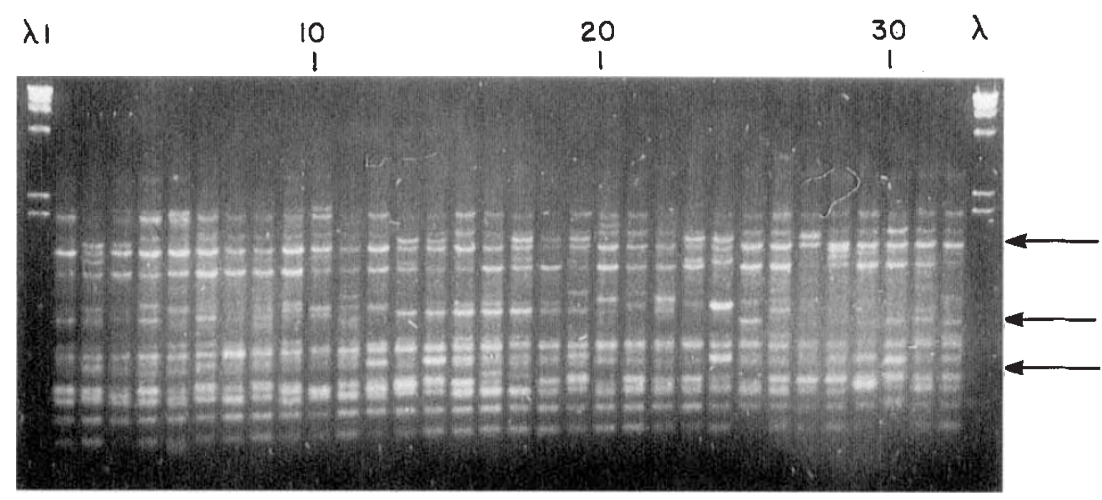

Fig. 2 Bands amplified from 32 Eucalyptus globulus ssp. globulus individuals by primer OPC-19; some polymorphic bands are indicated by arrows. Amplification products were electrophoresed through a 1.4 per cent agarose gel and visualized by ethidium bromide staining.
Table 2 RAPD primers used in a survey of Eucalyptus globulus

\begin{tabular}{lrrc}
\hline Primer & $N(t)$ & $N(p)$ & $N(P<0.05)$ \\
\hline OPC-01 & 12 & 11 & 3 \\
OPC-19 & 19 & 17 & 4 \\
OPD-05 & 18 & 18 & 5 \\
OPE-03 & 20 & 17 & 5 \\
OPE-07 & 14 & 9 & 3 \\
OPE-14 & 15 & 15 & 3 \\
OPE-18 & 15 & 14 & 5 \\
OPE-20 & 12 & 12 & 4 \\
OPF-01 & 17 & 16 & 6 \\
OPF-04 & 20 & 20 & 8 \\
Total & 162 & 149 & 46 \\
\hline
\end{tabular}

Total number of bands scored for each primer $[N(t)]$ and the number of those bands that were polymorphic $[N(p)]$ are shown.

For each primer the number of bands found to differ significantly between subspecies cores, using a contingency $\chi^{2}$-test, at the $P<0.05$ level is also shown.

(PC2) differentiates southern Tasmanian localities from the localities of southern Victoria (Fig. 3a). There is more or less continuous genetic variation between the ssp. globulus in southern Tasmania and the Victorian localities, with the Bass Strait Island localities intermediate. The King Island localities $(45,46)$ deviate slightly away from ssp. globulus, in the direction of the other subspecies (Fig. 3a). However, intergrade localities in Victoria, which are intermediate between pseudoglobulus/bicostata and ssp. globulus on capsule morphology (Jordan et al., 1993), do not deviate in this direction. Subspecies bicostata is separated from ssp. maidenii and ssp. pseudoglobulus by PC3 (Fig. 3b). Along this principal component the King Island localities deviate away from the main ssp. globulus localities in the direction of ssp. bicostata.

\section{Cluster analyses}

Clustering of localities only occurred when the average distance between clusters was high, indicating large differences between localities (Fig. 4). The most similar localities, Cape Patton and West Cape Barren, are geographically distant. Although there are many inconsistencies at the local level, the clustering does form groups that correlate broadly with geography. Group A comprises localities from within Tasmania exclusively whereas group B contains only localities from Victoria. Group $\mathrm{C}$ is a large mixed group containing some southern Victorian localities, some Furneaux region localities and several southern Tasmanian localities. Within this group, three subgroupings can be identified; two of these contain only Tasmanian localities (ii and iii) whereas the third (i) is less resolved and contains some coastal localities from southern Victoria (Cape Patton, Lorne and Hedley), localities from the Furneaux Group (Clarke and Cape Barren Islands) and one locality from northern Tasmania (St. Helens). The three Flinders Island localities cluster together, but the northern locality is the most deviant of the three (group D). Of the King Island localities, the central one has affinities with the Strath Bogie locality of ssp. bicostata (group E) whereas the southern locality is one of several outliers to the whole complex. The ssp. pseudoglobulus and maidenii localities cluster together (group F). Several localities are clearly genetic outliers. The Jeeralang North locality is an outlier to groups A and $B$, and the Moogara and Macquarie Harbour localities are outliers to the main ssp. globulus complex (groups A-E). The Lighthouse, South King Island and Toombullup (ssp. bicostata) localities are outliers to the whole complex. However, the position of the Toombullup locality should be treated with caution as its band frequencies are biased toward one sample because two individuals from this locality contain a large amount of unscorable bands.

Average Linkage Clustering of regions (Fig. 5) indicated that the closest affinities occur between the 
Table 3 Analysis of Molecular Variance (AMOvA) for Eucalyptus globulus

\begin{tabular}{|c|c|c|c|c|c|}
\hline Source of variation & d.f. & $\begin{array}{c}\text { MSD } \\
(\times 100)\end{array}$ & $\begin{array}{l}\text { Variance } \\
\text { component } \\
(\times 100)\end{array}$ & $\%$ Total & $P$ \\
\hline \multicolumn{6}{|l|}{ A. Subspecies cores } \\
\hline Between subspecies & 3 & 38.9 & 1.5 & 9.5 & $<0.01$ \\
\hline Between localities & 12 & 23.3 & 2.6 & 16.2 & $<0.01$ \\
\hline Within localities & 53 & 11.9 & 11.9 & 74.3 & \\
\hline \multicolumn{6}{|c|}{ B. Subspecies globulus + all intergrades } \\
\hline Between regions & 5 & 31.8 & 0.5 & 3.5 & $<0.01$ \\
\hline Between localities & 22 & 23.3 & 2.4 & 16.4 & $<0.01$ \\
\hline Within localities & 113 & 12.0 & 12.0 & 80.2 & \\
\hline \multicolumn{6}{|l|}{ C. Regional analyses } \\
\hline \multicolumn{6}{|l|}{ 1. Otway Ranges } \\
\hline Between & 4 & 20.9 & 1.6 & 10.8 & $<0.01$ \\
\hline Within & 19 & 13.2 & 13.2 & 89.2 & \\
\hline \multicolumn{6}{|l|}{ 2. South Gippsland } \\
\hline Between & 4 & 19.1 & 1.7 & 12.8 & $<0.01$ \\
\hline Within & 16 & 11.9 & 11.9 & 87.2 & \\
\hline \multicolumn{6}{|l|}{ 3. West Coast Central } \\
\hline Between & 1 & 32.1 & 4.1 & 25.7 & $<0.01$ \\
\hline Within & 8 & 11.8 & 11.8 & 74.3 & \\
\hline \multicolumn{6}{|l|}{ 4. East Coast Central } \\
\hline Between & 1 & 25.7 & 2.8 & 18.9 & $<0.01$ \\
\hline Within & 8 & 11.9 & 11.9 & 81.1 & \\
\hline \multicolumn{6}{|l|}{ 5. East Coast North } \\
\hline Between & 1 & 29.2 & 3.7 & 25.7 & $<0.01$ \\
\hline Within & 8 & 10.7 & 10.7 & 74.3 & \\
\hline \multicolumn{6}{|l|}{ 6. East Coast South } \\
\hline Between & 2 & 23.3 & 2.3 & 15.5 & $<0.01$ \\
\hline Within & 11 & 12.5 & 12.5 & 84.5 & \\
\hline \multicolumn{6}{|l|}{ 7. Derwent Valley } \\
\hline Between & 2 & 26.8 & 3.1 & 19.7 & $<0.01$ \\
\hline Within & 11 & 12.5 & 12.5 & 80.3 & \\
\hline \multicolumn{6}{|l|}{ 8. Furneaux Group } \\
\hline Between & 4 & 18.5 & 1.4 & 11.1 & $<0.01$ \\
\hline Within & 19 & 11.6 & 11.6 & 88.9 & \\
\hline \multicolumn{6}{|l|}{ 9. King Island } \\
\hline Between & 1 & 24.5 & 3.7 & 26.2 & $<0.01$ \\
\hline Within & 6 & 10.5 & 10.5 & 73.8 & \\
\hline \multicolumn{6}{|l|}{ 10. Lighthouse } \\
\hline Within & 3 & 8.9 & 8.9 & 100.0 & \\
\hline \multicolumn{5}{|l|}{ 11. Port Davey } & \\
\hline \multicolumn{6}{|l|}{ 12. Subspecies bicostata } \\
\hline Between & 1 & 14.0 & 2.5 & 20.2 & $<0.01$ \\
\hline Within & 3 & 10.0 & 10.0 & 79.9 & \\
\hline \multicolumn{6}{|l|}{ 13. Subspecies maidenii } \\
\hline Between & 1 & 23.1 & 2.2 & 15.5 & $<0.01$ \\
\hline Within & 8 & 12.0 & 12.0 & 84.5 & \\
\hline \multicolumn{6}{|c|}{ 14. Subspecies pseudoglobulus } \\
\hline Between & 1 & 14.4 & 0.7 & 5.1 & 0.14 \\
\hline Within & 4 & 12.4 & 12.4 & 94.9 & \\
\hline
\end{tabular}

Analysis was carried out for the localities representing (A.) subspecies cores, (B.) the complete dataset minus ssp. bicostata, maidenii and pseudoglobulus, and (C.) for each region separately. Mean squared deviations (MSDs), variance component estimates, percentages of total variation (\%Total) contributed by each component and the probability $(P)$ of obtaining a more extreme estimate by chance alone are presented. For the within-region analyses, 'Between' and 'Within' refer to betweenand within-locality variation for each region. 

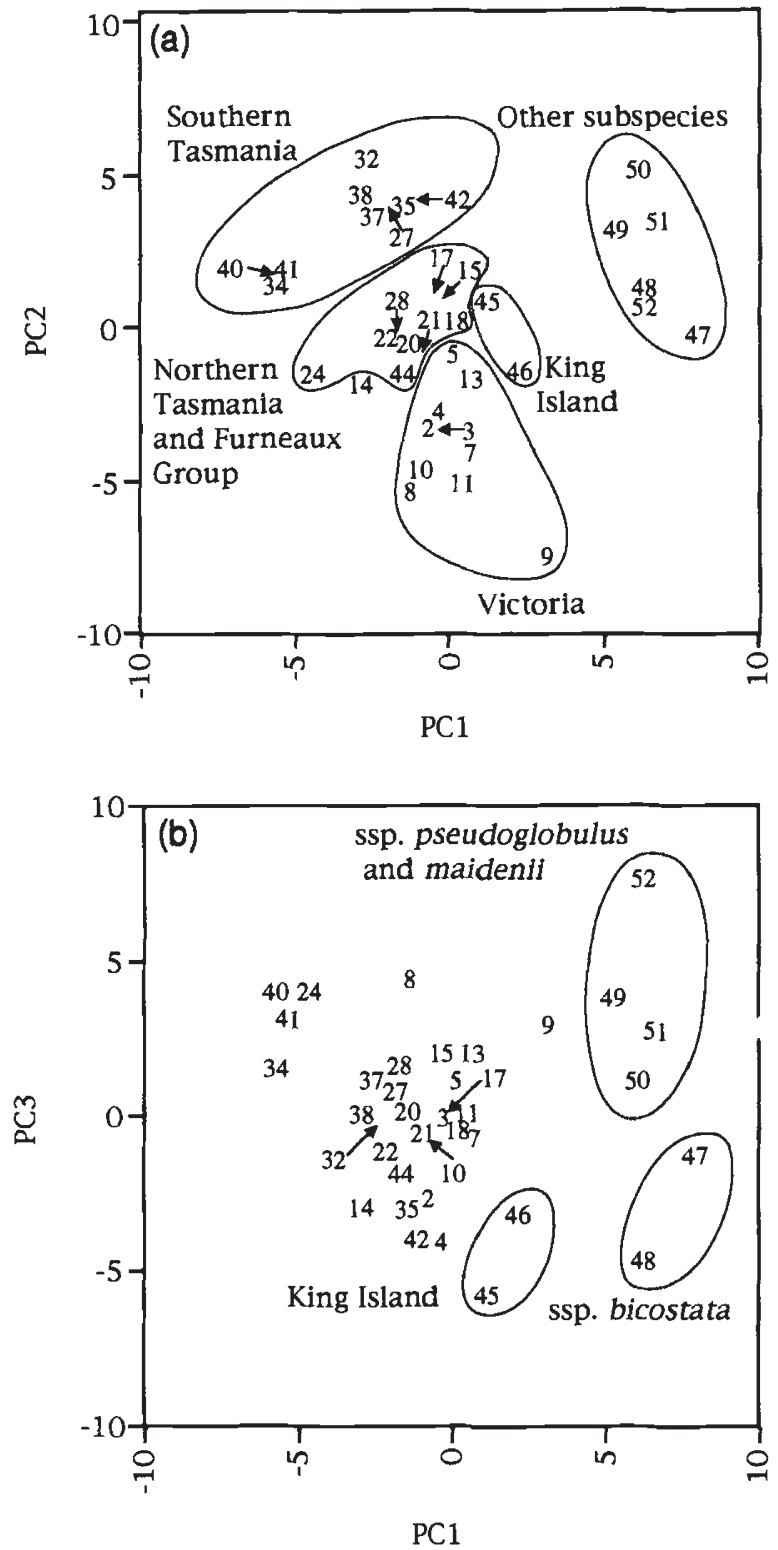

Fig. 3 Principal components analysis of RAPD phenotypes in Eucalyptus globulus. Principal components one, two and three account for 12.2 per cent, 10.2 per cent and 8.3 per cent of the total variation, respectively. (a) Plot of the first two principal components. The geographical distribution of each group is shown in Fig. 1. The term 'other subspecies' refers to ssp. maidenii, ssp. pseudoglobulus and ssp. bicostata. (b) Plot of the first and third principal components. Principal component three separates ssp. bicostata from ssp. pseudoglobulus and ssp. maidenii.

Otway Ranges and Furneaux regions which link with the Gippsland region to form a relatively well defined cluster. The ssp. globulus regions of eastern Tasmania cluster together and then fuse with the South Gippsland and Otway regions. The West Coast Central
Average distance between clusters

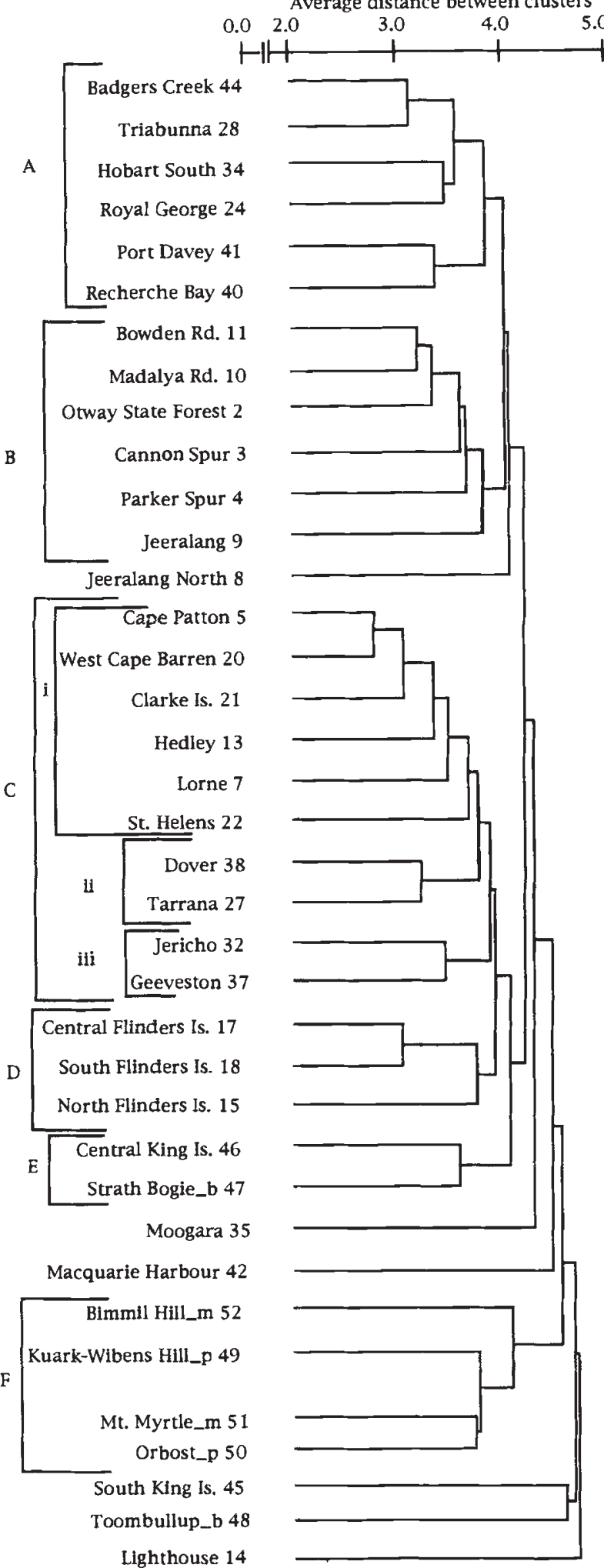

Fig. 4 Average Linkage Clustering of Eucalyptus globulus localities based on RAPD phenotype. The numbers are locality codes from Table 1. Letters indicate major groupings as identified in Results section. Subspecies bicostata, ssp. maidenii and ssp. pseudoglobulus are indicated by _ b, _m and $\_$, respectively.

c The Genetical Society of Great Britain, Heredity, 74, 628-637. 


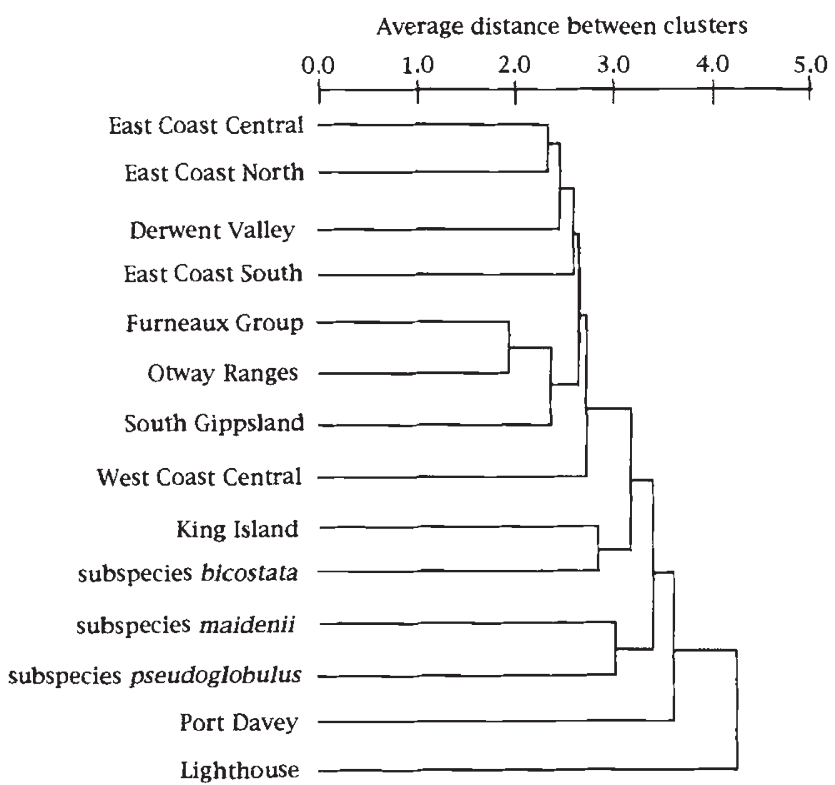

Fig. 5 Average Linkage Clustering of Eucalyptus globulus regions, as designated in Table 1, based on RAPD phenotype.

Tasmanian region is an outlier to this cluster. King Island is clearly an outlier to the main ssp. globulus regions and fuses with ssp. bicostata at a similar level as ssp. pseudoglobulus fuses with ssp. maidenii. In this analysis ssp. maidenii has closest affinities to ssp. pseudoglobulus and ssp. bicostata to ssp. globulus. The latter association arises from the affinities of the intermediate King Island region to ssp. bicostata, and is not evident when King Island is excluded from the analysis. In this case ssp. bicostata is as different from ssp. globulus regions as it is from the other subspecies. The Port Davey and Lighthouse localities are outliers to the whole $E$. globulus complex.

\section{Discussion}

The majority of RAPD variation in E. globulus is found within rather than between localities which agrees with the findings of Potts \& Jordan (1994) based on growth traits of $E$. globulus ssp. globulus. These results are also consistent with the general trend in other outcrossing Australian tree species reported by Moran (1992) based on allozyme variation. The level of and partitioning of RAPD variation has been examined in both outcrossing and selfing plants. The results of these studies have been variable, no doubt dependent on the patterns of geographical distribution and the breeding systems of the species involved. In buffalograss (Buchloë dactyloides) for example, Huff et al. (1993) found that 72.9 per cent and 80.5 per cent of the variation in the two geographical regions studied was the result of within-population variation. This level is comparable with the 73.8 per cent to 94.9 per cent found for $E$. globulus, although the regional differentiation was greater in buffalograss. In contrast, much lower percentages of the variation were found within populations of Hordeum spontaneum (43 per cent; Dawson et al., 1993), which has high selfing levels, and in the leguminous tree Gliricidia sepium (Chalmers et al., 1992).

Analysis of RAPD variation found no areas of intergradation between ssp. globulus and the other three subspecies, which contrasts with previous reports of extensive intergradation based on morphology. Jordan et al. (1993) suggest that ssp. bicostata intergrades with ssp. pseudoglobulus, and that ssp. globulus intergrades with part of this continuum. Many of the Victorian localities are part of this continuum and are well differentiated from core localities. Whereas the PCA shows that the Victorian intergrade localities are well differentiated from the subspecies cores, they are not intermediate in RAPD phenotype, as one would expect if they were recent intergrades. The majority of Victorian localities do not deviate towards the non-globulus subspecies in the PCA, but are one extreme of a latitudinal cline ending in southern Tasmanian ssp. globulus. These Victorian localities are therefore better referred to as morphological intermediates at this stage.

According to the cluster analysis ssp. globulus is closer to ssp. bicostata than to either ssp. maidenii or ssp. pseudoglobulus. However, this link is entirely due to the affinities of ssp. bicostata to the intermediate King Island region. If King Island is removed from the analysis ssp. bicostata is equally distant from ssp. globulus, ssp. maidenii and ssp. pseudoglobulus. Trees with ssp. bicostata-like capsules have been identified on northern Flinders Island, western Tasmania and the Otway regions, but only a few such phenotypes were reported on King Island (Jordan et al., 1993). The localities sampled on King Island are relatively isolated, and the high variances between the localities coupled with the low variances within localities are consistent with the effects of inbreeding reported by Potts \& Jordan (1994). Inbreeding may have influenced the affinities of the King Island localities, although it is possible that they are remnants of ssp. bicostata, or its intergrades. This contrasts with previous studies based on capsule morphology which have classified the King Island region as core ssp. globulus (Jordan et al., 1993), although the authors did have some doubts about this classification.

Despite the marked morphological differentiation occurring between localities in the Furneaux group 
(Kirkpatrick, 1975a; Potts \& Jordan, 1994), the between-locality genetic variance based on RAPD phenotype is low in this region compared to other regions, indicating little differentiation between localities. However, a dichotomy in the Furneaux group is revealed by both the locality (Fig. 4) and the individual (data not shown) cluster analyses. The Flinders Island localities form a separate group to the Clarke Island and West Cape Barren localities which are linked to several southern Victorian and northern Tasmanian localities. A similar dichotomy occurs in juvenile leaf morphology (Potts \& Jordan, 1994), but not in capsule morphology. This differentiation is, in fact, almost the opposite to that found based on capsule morphology which identifies all localities in the Furneaux Group except northern Flinders Island as good ssp. globulus (Jordan et al., 1993).

Previously some localities used in this study have been identified as outliers, either on capsule morphology (Jordan et al., 1993) or on growth traits (Jordan et al., 1994). The Lighthouse locality is an outlier to the whole E. globulus complex in both cluster analyses (Figs 4 and 5) and is separated from the other localities by principal component five (data not presented). The Lighthouse locality has also been shown to differ significantly from the ssp. globulus capsule phenotype (Jordan et al., 1993) and to have aberrant growth traits (Jordan et al., 1994) indicating that its taxonomic status requires reassessment. Potts \& Jordan (1993) present evidence suggestive of hybridization occurring in the Macquarie Harbour and Port Davey localities. Macquarie Harbour is an outlier based on RAPD phenotype (Fig. 4) and on capsule morphology (Jordan et al., 1993), supporting this suggestion. The RAPD results for Port Davey are somewhat contradictory. In the regional clustering Port Davey is an outlier to the rest of the E. globulus complex; however, in both the locality and individual (data not shown) clustering this locality is linked to Recherche Bay. This link is supported to some extent by juvenile leaf morphology (Potts \& Jordan, 1994), but not by capsule morphology (Jordan et al., 1993).

Although some similarities between the traditional morphological studies and this RAPD study are evident, RAPDs have provided new insights into the patterns of variation within the E. globulus complex (e.g. the affinities of the Furneaux group, King Island and the localities outside core subspecies areas). Differences between approaches are probably the result of the scope of variation being examined by each technique: RAPDs sample a random section of the genome whilst morphological traits such as capsule morphology may be controlled by only a few genes subject to varying levels of selection. The fact that much of the
RAPD variation in ssp. globulus is found within localities suggests that sampling from a few localities for either breeding or conservation may capture a large proportion of the variation within the subspecies. Nevertheless, sampling from a wide range of localities is still advisable as there are significant RAPD differences between localities and regions of ssp. globulus. In addition, the distribution of RAPD variation may not necessarily reflect the pattern of variation in adaptive genes, although in this case the RAPD results are consistent with those obtained from growth traits.

\section{Acknowledgements}

The authors thank Mandy Watson for technical assistance, Peter Gore, Paul Tilyard and Maarten Krugsman (APM) for help with collection of leaf material, and Dr Greg Jordan for discussion and help with data analysis.

\section{References}

BorRALHO, N. M. G., COTTERILl, P. P. AND KANOWSKI, P. J. 1992 a. Genetic parameters and gains expected from selection for dry weight in Eucalyptus globulus ssp. globulus in Portugal. Forest Sci., 38, 80-94.

BORRALHO, N. M. G., KANOWSKI, P. J. AND COTTERILL, P. P. 1992 b. Genetic control of growth of Eucalyptus globulus in Portugal. Silvae Genet., 41, 39-45.

CARLSON, J. E., TULSIERAM, L. K., GLAUBiTZ, J. C., LUK, V. W. K., KAUFFELDT, C. AND RUTLEDGE, R. 1991. Segregation of random amplified DNA markers in $F_{1}$ progeny of conifers. Theor. Appl. Genet., 83, 194-200.

CHALMERS, K. J., WAUGH, R., SPENT, J. I., SIMONS, A. J. AND POWELL, W. 1992. Detection of genetic variation between and within populations of Gliricidia sepium and G. maculata using RAPD markers. Heredity, 69, 465-472.

CHIPPENDALE, G. M. 1988. Eucalyptus, Angophora (Myrtaceae). Flora of Australia, vol. 19. Government Publishing Service, Canberra.

DAWSON, I. K., CHALMERS, K. J., WAUGH, R. AND POWELl, W. 1993. Detection and analysis of genetic variation in Hordeum spontaneum populations from Israel using RAPD markers. Mol. Ecol., 2, 151-159.

DOYLE, J. J. AND DOYLE, J. L. 1990. Isolation of plant DNA from fresh tissue. Focus, 12, 13-14.

EXCOFFIER, L., SMOUSE, P. E. AND QUATTRO, J. M. 1992. Analysis of molecular variance inferred from metric distances among DNA haplotypes: application to human mitochondrial DNA restriction data. Genetics, 131, 479-491.

FANG, G., HAMMER, S. AND GRUMET, R. 1992. A quick and inexpensive method for removing polysaccharides from plant genomic DNA. Biotechniques, 13, 52-55.

GRATTAPAGLIA, D. AND SEDEROFF, R. 1994. Genetic linkage maps of Eucalyptus grandis and E. urophylla using a pseudotestcross mapping strategy and RAPD markers. Genetics, 137, 1121-1137. 
HU, J. AND QUIROS, C. F. 1991. Identification of broccoli and cauliflower cultivars with RAPD markers. Pl. Cell Rep., 10, 505-511.

HUFF, D. R., PEAKALL, R. AND SMOUSE, P. E. 1993. RAPD variation within and among natural populations of outcrossing buffalograss [Buchloe dactyloides (Nutt.) Engelm.]. Theor. Appl. Genet., 86, 927-934.

JORDAN, G. J., BORRALHO, N. M. G., TILYARD, P. AND POTTS, B. M. 1994. Identification of races in Eucalyptus globulus ssp. globulus for growth characteristics in Tasmania. Silvae Genet. (in press).

JORDAN, G. J., POTTS, B. M., KIRKPATRICK, J. B. AND GARDINER, C. 1993. Variation in the Eucalyptus globulus complex revisited. Aust. J. Bot., 41, 763-785.

KAZAN, K., MANNERS, J. M. AND CAMERON, D. F. 1993. Inheritance of random amplified polymorphic DNA markers in an interspecific cross in the genus Stylosanthes. Genome, 36, $50-56$.

KIRKPATRICK, J. B. 1974. The numerical and intraspecific taxonomy of Eucalyptus globulus Labill. (Myrtaceae). Bot. J. Linn. Soc., 69, 89-104.

KIRKPATRICK, J. B. 1975a. Geographical variation in Eucalpytus globulus. Forestry and Timber Bureau Canberra Bulletin, No. 47. Australian Government Publishing Service, Canberra.

KIRKPATRICK, J. B. 1975 b. Natural distribution of Eucalyptus globulus Labill. Aust. Geog., 13, 22-35.

KLEIN-LANKHORST, R. M., VERMUNT, A., WEIDE, R., LIHARSKA, T. AND ZABEL, P. 1991. Isolation of molecular markers for tomato (Lycopersicon esculentum) using random amplified polymorphic DNA (RAPD). Theor. Appl. Genet., 83, $108-114$

LANDRY, B. S., DEXTRAZE, L. AND BoIVIN, G. 1993. Random amplified polymorphic DNA markers for DNA fingerprinting and genetic variability assessment of minute parasitic wasp species (Hymenoptera: Mymaridae and Trichogrammatidae) used in biological control programs of phytophagous insects. Genome, 36, 580-587.

MAILER, R. J., SCARTH, R. AND FRISTENSKY, B. 1994. Discrimination among cultivars of rapeseed (Brassica napus L.) using
DNA polymorphisms amplified from arbitrary primers. Theor. Appl. Genet., 87, 697-704.

MORAN, G. F. 1992. Patterns of genetic diversity in Australian tree species. New Forests, 6, 49-66.

MUONA, o. 1990. Population genetics in forest tree improvement. In: A. H. D. Brown, M. T. Clegg, A. L. Kahler and B. S. Weir (eds) Plant Population Genetics, Breeding and Genetic Resources, pp. 282-298. Sinauer, Sunderland, MA.

POTTS, B. M. AND JORDAN, G. J. 1994. The spatial pattern and scale of variation in Eucalyptus globulus Labill. ssp. globulus: variation in seedling abnormalities and early growth. Aust. J. Bot., 42, 471-492.

PUTERKA, G. J., BLACK, W. C., IV, STEINER, W. M. AND BURTON, R. L. 1993. Genetic variation and phylogenetic relationships among worldwide collections of the Russian wheat aphid, Diuraphis noxia (Mordvilko), inferred from allozyme and RAPD-PCR markers. Heredity, 70, 604-618.

SAS 1988. SAS/STAT User's Guide for Personal Computers. Release 6.03 edition. SAS Institute, Cary, NC.

SNEATH, P. H. A. AND SOKAL, R. R. 1973. Numerical Taxonomy. W. H. Freeman, San Fransisco.

SOBRAL, B. W. S. AND HONEYCUTT, R. J. 1993. High output genetic mapping of polyploids using PCR-generated markers. Theor. Appl. Genet., 86, 105-112.

VOLKER, P. AND ORME, K. 1988. Provenance trials of Eucalyptus globulus and related species in Tasmania. Australian Forestry, 51, 257-265.

WELSH, J. AND McCleLlaND, M. 1990. Fingerprinting genomes using PCR with arbitrary primers. Nucl. Acids Res., 18, 7213-7218.

WILLIAMS, I. G. K., KUBELIK, A. R., LIVAK, K. J., RAFALSKI, J. A. AND TINGEY, S. v. 1990. DNA polymorphisms amplified by arbitrary primers are useful as genetic markers. Nucl. Acids Res., 18, 6531-6535.

YU, L.X. AND NGUYEN, H. T. 1994. Genetic variation detected with RAPD markers among upland and lowland rice cultivars (Oryza sativa L.). Theor. Appl. Genet., 87, $668-672$. 